FIU Law Review

Spring 2017

\title{
Whose Land Is It Anyway? The Territorial and Maritime Dispute Over the Spratly Islands
}

Nina Roca

Florida International University College of Law

Follow this and additional works at: https://ecollections.law.fiu.edu/lawreview

Part of the International Law Commons

Online ISSN: 2643-7759

\section{Recommended Citation}

Nina Roca, Whose Land Is It Anyway? The Territorial and Maritime Dispute Over the Spratly Islands, 12 FIU L. Rev. 391 (2017).

DOI: https://dx.doi.org/10.25148/lawrev.12.2.10

This Comment is brought to you for free and open access by eCollections. It has been accepted for inclusion in FIU Law Review by an authorized editor of eCollections. For more information, please contact lisdavis@fiu.edu. 


\title{
WHOSE LAND IS IT ANYWAY? THE TERRITORIAL AND MARITIME DISPUTE OVER THE SPRATLY ISLANDS
}

\author{
Nina Roca*
}

\section{INTRODUCTION}

In the past few years, China, Vietnam, the Philippines, Malaysia, and Brunei have been attempting to untie the Gordian knot that has arisen over the Spratly Islands. The Spratly Islands archipelago is a cluster of approximately 100 islands, islets, cays, reefs, atolls, rocks, shoals, and banks in the South China Sea. ${ }^{1}$ They are located between $4^{\circ}$ and $11^{\circ} 3^{\prime}$ North Latitude and 109 $30^{\prime}$ and $117^{\circ} 50^{\prime}$ East Latitude. ${ }^{2}$ Including territorial waters, the Spratly Islands cover approximately 69,500 square miles. $^{3}$ The majority of the islands are too small and arid to support permanent settlements, and none of the islands have any indigenous inhabitants. ${ }^{4}$ The islands also have limited fresh water sources and few

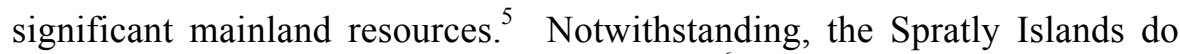
have strategic, political, and economic value. ${ }^{6}$ The Spratly Islands' worth lies in the sea-lanes that run through the islands, which are needed for trade into East Asia; their extensive fishing waters, which the controlling state could restrict a state's access to; and the hydrocarbon, ${ }^{7}$ oil, and gas deposits, which are presumed to be under the sea-beds. ${ }^{8}$

\footnotetext{
* J.D. Candidate, May 2017, Florida International University College of Law. I would like to thank Professor Manuel Gomez for his guidance; Riya Resheidat for her edits and comments; and Louis Holzberg for his advice and feedback.

1 See Christopher C. Joyner, The Spratly Islands Dispute in the South China Sea: Problems, Policies, and Prospects for Diplomatic Accommodation, in INVESTIGATING BUILDING MEASURES IN THE ASIA-PACIFIC REgION 53, 55 (Rajeet K. Singh ed., 1999).

2 Id. at 56.

3 Id.

4 See generally DAVID HANCOX \& VICTOR PRESCOTT, MARITIME BRIEFING: A GEOGRAPHICAL DESCRIPTION OF THE SPRATLY ISLANDS AND AN ACCOUNT OF HYDROGRAPHIC SURVEYS AMONGST THOSE ISLANDS (Clive Schofield ed., vol. 1 no. 6 1995).

5 Id.

$6 \quad I d$

7 Hydrocarbons are organic compounds "found in coal, crude oil, and natural gas."Hydrocarbon,
} BUS. DICTIONARY, http://www.businessdictionary.com/definition/hydrocarbon.html (last visited Jan. 6, 2017). They "are used as fuels, solvents, and raw materials" for products including "dyes, pesticides, and plastics." Id. They are predominantly used as a combustible fuel source. See Richard M.J. Renneboog, Uses of Hydrocarbons, SCIENCEIQ.COM, http://www.scienceiq.com/Facts/UsesOfHydr ocarbons.cfm (last visited Jan. 6, 2017).

8 See Jill Goldenziel, International Law is the Real Threat to China's South China Sea Claims, Diplomat (Nov. 3, 2015), http://thediplomat.com/2015/11/international-law-is-the-real-threat-to- 
The end of the Cold War brought about the collapse of the Soviet Union, and its subsequent departure from Cam Ranh Bay; the United States' closure of naval bases in the Philippines; and Vietnam's withdrawal from Cambodia. ${ }^{9}$ This created a strategic vacuum in the South China Sea. ${ }^{10}$ These events also spurred several East Asian countries to evaluate the strategic and national security implications of sovereignty claims to the islands in the South China Sea. ${ }^{11}$ Currently, five states, China, the Philippines, Vietnam, Malaysia, and Brunei, claim to be the sovereign owners of the islands, but this is still an unsettled international dispute. ${ }^{12}$ Although there are five claimants, China and Vietnam are the only states to claim title to the entire island group while the Philippines, Malaysia, and Brunei only claim title to a portion. ${ }^{13}$ Brunei does not lay claim to any of the islands, but does claim the area that falls within its exclusive economic zone ("EEZ"). ${ }^{14}$ The majority of these claims are overlapping. ${ }^{15}$

Under the United Nations Convention on the Law of the Sea ("UNLCLOS"), which China, the Philippines, Vietnam, Malaysia, Brunei, and other states have all ratified, a state is allowed to establish a twelvemile territorial sea and a 200-mile EEZ from its border with the ocean. ${ }^{16}$ If one of these states were to establish legal sovereignty over the Spratly Islands, it would be entitled to exclusive rights to explore and exploit the islands, and the surrounding sea-bed and ocean. ${ }^{17}$ Furthermore, it would have the right to control the sea-lanes that run in-between the Spratly Islands. ${ }^{18}$ These sea-lanes are used by foreign commercial fishing boats and are the only way to reach the South Asian ports. ${ }^{19}$ The state would also

chinas-south-china-sea-claims; Joyner, supra note 1, at 55.

9 See Joyner, supra note 1 , at 53.

10 Id.

$11 I d$.

12 See Ice Cases: Spratly Islands Dispute, INVENTORY OF CONFLICT \& ENVIRONMENT (May 1997), http://www1.american.edu/TED/ice/Spratly.htm.

13 Id.

14 See Karen Friar, China's Artificial Islands in Before-and-After Photos, MARKET WATCH (Jan. 4, 2016, 9:32 AM), http://www.marketwatch.com/story/chinas-artificial-islands-in-before-and-afterphotos-2015-10-27.

15 See Derek Watkins, What China Has Been Building in the South China Sea, N.Y. TIMES, http://www.nytimes.com/interactive/2015/07/30/world/asia/what-china-has-been-building-in-the-southchina-sea.html?_r=1 (last updated Oct. 27, 2015).

16 See United Nations Convention on the Law of the Sea, Dec. 10, 1982, 1833 U.N.T.S. 397 (entered into force Nov. 16, 1994) [hereinafter United Nations Convention on Law of the Sea].

17 Id.

18 Press Release, Ministry of Foreign Affairs of the People's Republic of China, Position Paper of the Government of the People's Republic of China on the Matter of Jurisdiction in the South China Sea Arbitration Initiated by the Republic of the Philippines (Dec. 7, 2014), http://fmprc.gov.cn/mfa_eng/ zxxx_662805/t1217147.shtml.

19 See Joyner, supra note 1, at 57. 
have control of the extensive fishing waters around the island group and could control which states and private entities have access to these waters. Moreover, it could extract and utilize the extensive amounts of hydrocarbons presumed to be under the ocean bed. ${ }^{20}$

When a state ratifies UNCLOS, it agrees to settle any disputes arising from the interpretation or application of UNCLOS through international arbitration. Depending on the type of dispute and other factors, UCNLOS gives jurisdiction to the International Tribunal for the Law of the Sea ("ITLS"), the International Court of Justice ("ICJ"), or an international tribunal constituted according to Annex VII or Annex VIII of UNCLOS. ${ }^{21}$ Pursuant to Article 287(3) of UNCLOS, if a state has not expressed a preference of dispute resolution available under 287(1), then arbitration under Annex VII is the default means of settlement. ${ }^{22}$ Also, pursuant to Article 287(5), if the states involved in the dispute have not agreed to the same method of dispute settlement, Annex VII will be the default means of settlement. $^{23}$ This is provided that the states have not stated any reservations or optional exceptions per Article 298. ${ }^{24}$ The Permanent Court of Arbitration ("PCA") is an arbitral tribunal constituted in accordance with Annex VIII of UNCLOS. ${ }^{25}$ Both the ICJ and the PCA have recently decided cases that involved interpreting UNCLOS. ${ }^{26}$ But, one of the problems that arises with decisions by the ICJ is that they are not enforceable; compliance is often urged by conscience or morality. ${ }^{27}$ Although China, Vietnam, the Philippines, Malaysia, and Brunei are all signatories to the United Nations Convention on the Recognition and Enforcement of Arbitral Awards of $1958,{ }^{28}$ China is not likely to honor any

20 Id.

21 See United Nations Convention on the Law of the Sea, PERMANENT COURT OF ARBITRATION, https://pca-cpa.org/en/services/arbitration-services/unclos/ (last visited Jan. 6, 2017).

$22 \quad I d$.

23 Id.

$24 I d$.

$25 I d$.

26 See generally Sovereignty Over Pulau Ligitan and Pulau Sipadan (Indon. v. Malay.), Judgment, 2002 I.C.J. Rep. 625 (Dec. 17); Island of Palmas (Neth. v. U.S.), Special Agreement, 2 R. Int'l. Arb. Awards 829 (Perm. Ct. Arb. 1928).

27 See W. M. Reisman, The Enforceability of International Judgments and Awards, 63 AM. J. INT'L L. 1, 2 (1969).

28 The Convention's principal aim is that foreign and non-domestic arbitral awards will not be discriminated against, and it obliges parties to ensure such awards are recognized and generally capable of enforcement in its jurisdiction in the same way as domestic awards. An ancillary aim of the Convention is to require courts of parties to give full effect to arbitration agreements by requiring courts to deny the parties access to court in contravention of their agreement to refer the matter to an arbitral tribunal. See UNITED NATIONS COMMISSION ON INTERNATIONAL TRADE LAW ("UNCITRAL"), Convention on the Recognition and Enforcement of Foreign Arbitral Awards, UNCITRAL (1958), http://www.uncitral.org/pdf/english/texts/arbitration/NY-conv/New-York-Convention-E.pdf. 
decision made by the PCA or the ICJ since it has already challenged and rejected the jurisdiction of the PCA in the Spratly Islands dispute, and would likely challenge and reject the jurisdiction of the ICJ if it were to arise. $^{29}$

Also, China has previously refused to acknowledge the jurisdiction and authority of international courts. ${ }^{30}$ This is evident because it is one of the few states that have refused to recognize the jurisdiction of the ICJ as compulsory, and it recently denied the jurisdiction of the PCA to adjudicate the maritime jurisdiction of the Philippines in the South China Sea. Although China has historically declined to work through international courts, it has promoted peaceful negotiations and cooperation to resolve the dispute between the states involved with the Spratly Islands. China is a signatory to the Declaration on the Conduct of Parties in the South China Sea, a declaration of conduct signed in 2002 explicitly undertaking "to resolve territorial and jurisdictional disputes [in the South China Sea] by peaceful means, without resorting to the threat or use of force, through friendly consultations and negotiations by sovereign states directly concerned." ${ }^{31}$ Because of China's historic refusal to work through international courts, its recent rejection of the PCA's jurisdiction, and its previous willingness to participate in bilateral treaties with the competing states, the ideal solution for all parties involved in the dispute over the Spratly Islands would be to negotiate a treaty where they would set aside the territorial claims and establish a Joint Development Zone Agreement similar to the Joint Development Zone Agreement established by Nigeria and Sao Tome and Principe.

This comment will begin by discussing the historic and modern assertions that each state has made in support of its claims to the islands. It will also examine the very recent actions of each of the states in the South China Sea, which are leading to escalated tensions in the area. It will then examine each state's claims to the Spratly Islands and analyze the strengths and weaknesses of each claim in light of previous ICJ and PCA decisions and provisions of UNCLOS. It will then discuss the structure and content of the Nigeria and Sao Tome and Principe Joint Development Zone Agreement, and suggest the states disputing control over the Spratly Islands create a similar agreement.

29 Id.; see also Ministry of Foreign Affairs of the People's Republic of China, supra note 18.

30 China is not the only state to do this. The United States often also refuses to work through foreign courts because it believes that its court system is better able to resolve disputes.

31 Ass'n of Southeast Asian Nations ("ASEAN"), Declaration on the Conduct of Parties in the South China Sea, section 4 (Nov. 4, 2002), http://asean.org/?static_post=declaration-on-the-conduct-ofparties-in-the-south-china-sea-2. 


\section{BACKGROUND}

\section{A. China's Claims}

China's claims to the Spratly Islands are based on discovery and occupation, but, unfortunately for China, the names for the islands in the South China Sea change frequently in Chinese literature, making it difficult for researchers to track which islands China previously occupied. ${ }^{32}$ This is unfortunate for China because it makes it difficult for any court to substantiate its claims to the Spratly Islands. China affirms that the Spratly Islands were terra nullius ${ }^{33}$ prior to their discovery and that they have been explored, used, and occupied by Chinese fishermen since ancient times. ${ }^{34}$ In Chinese mythology, the islands in the South China Sea are collectively described as the "Tongue of the Dragon" and are portrayed as an inseparable part of China. ${ }^{35}$ According to China, starting in 111 B.C.E., under Emperor Wu Di of the Han Dynasty, it began exploiting the islands in the South China Sea. ${ }^{36}$ China claims that during this time the Spratly Islands were first discovered. ${ }^{37}$ Furthermore, starting in 1405, Emperor Cheng $\mathrm{Zu}$ of the Ming Dynasty sent an explorer, Cheng Ho, to utilize and settle the islands in the South China Sea and include them on maps as Chinese territory. ${ }^{38}$ This is the first time that the Spratly Islands were roughly charted. ${ }^{39}$ However, "ancient records are sparse, incomplete, and do not provide compelling evidence of routine occupation, effective administration, or assertion of sovereign control. $" 40$

China also claims to have maps from 1775, 1810, and 1817 demonstrating that it had discovered and occupied the islands in the South China Sea. ${ }^{41}$ Ch'en Lun Chiung, a Chinese scholar, also published a book

32 See Lee G. Cordner, The Spratly Islands Dispute and the Law of the Sea, 25 OCEAN DEV. \& INT'L L. 61, 62 (1994).

33 Terra nullius “is a Latin term that means land belonging to no one or no man's land. In international law, a territory which has never been subject to the sovereignty of any state, or over which any prior sovereign has expressly or implicitly relinquished sovereignty is terra nullius. Sovereignty over territory which is terra nullius can be acquired through occupation. International sea, and celestial bodies would come under the term terra nullius." Terra Nullius, USLEGAL, https://defintions.uslegal .com/t/terra-nullius/ (last visited Jan. 6, 2017).

34 See Cordner, supra note 32 , at 62.

35 Id.

36 See S. Yeh, Nansha Situation and International Law, 19 ECON. \& L. 27, 29 (1988).

37 Id.

$38 I d$.

39 See Cordner, supra note 32 , at 62.

$40 \quad I d$. at 63.

41 See Teh-Kuang Chang, China's Claim of Sovereignty Over Spratly and Parcel Islands: A Historical and Legal Perspective, 23 CASE WESTERN RES. J. INT’L L. 399, 405 (1991). 
in 1730, which geographically described the Spratly Islands. ${ }^{42}$ Moreover, British books from 1923 and French books from 1927 also have recorded that the Chinese were living on some of the islands in the South China Sea. ${ }^{43}$ However, a 1928 Chinese Government Report portrays the southernmost delimitation of Chinese territory as the Xisha Islands, also known as the Parcels, and makes no mention of the Spratly Islands. ${ }^{44}$

In the Sino-French Treaty of 1887, Vietnam was named as a French protectorate and France laid claims to the territory west of $105^{\circ} 43^{\prime}$ ' East of Paris, in effect ceding the territory east of this line to China. ${ }^{45}$ Because the Spratly Islands lie east of this line, China cites to this treaty to affirm that the Spratly Islands were under Chinese ownership. ${ }^{46}$ However, although the Spratly Islands do lie east of this line, the Spratly Islands were neither mentioned nor named in the treaty; the treaty does not include a northern, southern, or eastern line of demarcation; and respective interpretations of the treaty in Chinese and French are controversial. ${ }^{47}$

Since 1914, China has employed and developed what is known today as the "nine-dash line" in its maps. ${ }^{48}$ This line is used to delineate its claims to the South China Sea. ${ }^{49}$ Although China does claim that it was the first to discover and occupy the islands, it concedes that in 1930 and 1932 France began occupying a variety of the islands that China claimed belonged to China. ${ }^{50}$ China strongly protested the French government for taking the islands. ${ }^{51}$ In 1939, France relinquished their claims to the islands to Japan, and Japan took over the entire chain of islands in the South China Sea. ${ }^{52}$ Through this invasion, Japan established the first recorded permanent garrison and was the first to demonstrate effective sovereign control over the Spratly Islands. ${ }^{53}$ By 1945, Japan had surrendered and returned the islands to China; and, by 1946, China had regained physical possession of the islands. ${ }^{54}$

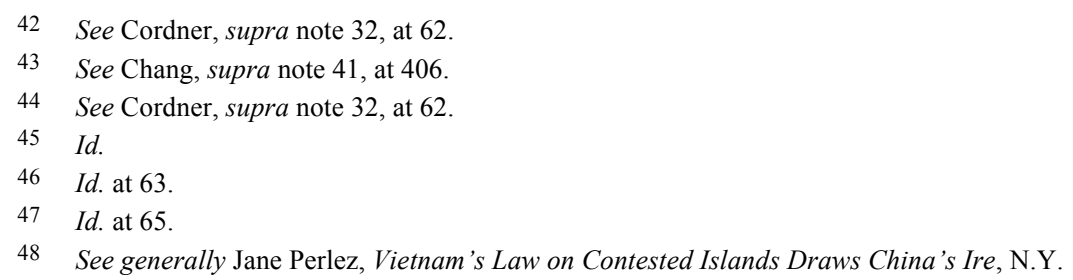

TIMES (June 21, 2012), http://www.nytimes.com/2012/06/22/world/asia/china-criticizes-vietnam-indispute-over-islands.html.

49 Id.; see also Friar, supra note 14.

50 See Chang, supra note 41 , at 406.

51 See Jianming Shen, Chinese Sovereignty Over the South China Sea Islands: A Historical Perspective, 1 CHINESE J. INT'L L. 94, 98 (2002).

52 See Chang, supra note 41, at 406; Shen, supra note 51, at 98.

53 See Cordner, supra note 32, at 64.

54 See Chang, supra note 41, at 406; see also Shen, supra note 51, at 98-99. 
China maintains that its claims to the Spratly Islands were further solidified by the San Francisco Peace Treaty of 1951 and the Sino-Japanese Treaty of 1952 because Japan formally renounced its claims to the Spratly Islands in both. ${ }^{55}$ Although Vietnam made claims to the islands at the San Francisco Peace Treaty of 1951, China asserts that these claims are null because China was not invited to participate in that treaty and because "Premier Zhou Enlai issued a statement reiterating China's unquestionable sovereignty over these islands and warning against any arrangement at the Conference that might be aimed at challenging or affecting China's sovereignty." ${ }^{56}$ Also, although Japan did formally renounce its claims to the Spratly Islands at the San Francisco Peace Treaty of 1951, it did not name a sovereign successor. ${ }^{57}$

In the 1950s and 1960s China's claims to the Spratly Islands were further challenged. Vietnam began to occupy some of the islands in the South China Sea and the Philippines declared sovereignty over various islands, claiming it discovered some of the Spratly Islands. ${ }^{58}$ Beginning in the 1960s, Malaysia and Brunei had also begun laying claims to some of the Spratly Islands by occupying certain islands. ${ }^{59}$ Tensions in the South China Sea escalated in 1974 when Vietnam and China had a battle over some of the islands that Vietnam had claimed. ${ }^{60}$ This resulted in China reclaiming some of the islands Vietnam previously occupied. ${ }^{61}$ Relations were further strained in 1987 and 1988 when two military encounters occurred between the Chinese and Vietnamese navies, which caused casualties on both sides. $^{62}$ In 1995, China had another military confrontation on the South China Sea, but this time with the Philippines' naval forces. ${ }^{63}$ Since then, the Philippines, Vietnam, and Malaysia have increased their military and non-military presence in the South China Sea to protect their respective claims. $^{64}$

In 2002, China signed an agreement with the Association of Southeast Asian Nations ("ASEAN") agreeing not to make any provocative moves in disputed territory. ${ }^{65}$ This included the agreement that none of the disputing

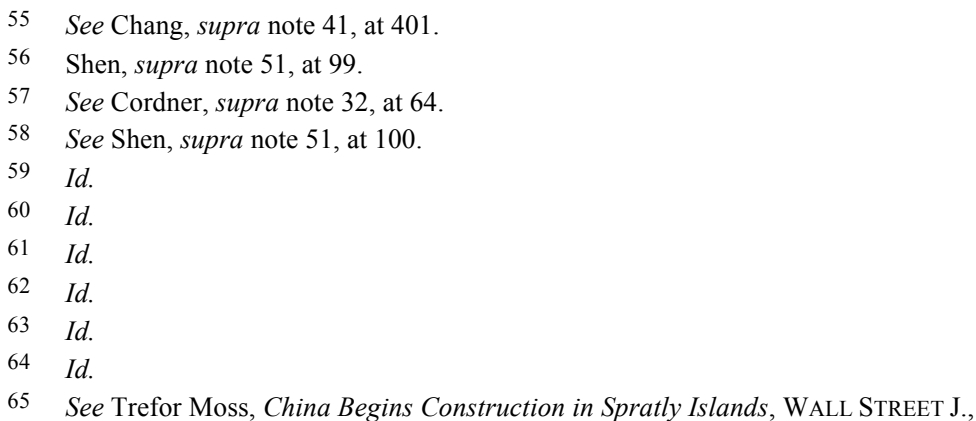
https://www.wsj.com/articles/SB10001424052702304908304579561123291666730 (updated May 14, 
countries would begin construction on disputed features. ${ }^{66}$ China violated this agreement in 2014 when it began construction on Johnson South Reef, a reef which the Philippines claimed possession of. ${ }^{67}$ That same year, China deployed a rig in the South China Sea. ${ }^{68}$ These actions were seen as assertive behavior, and therefore provocative moves prohibited by the agreement with ASEAN, by Vietnam, the Philippines, Malaysia, and Brunei, all of which have their own claims in the South China Sea. ${ }^{69}$

Recently, China has been building islands in the South China Sea, further straining the already tense relations with its Asian neighbors. ${ }^{70}$ It does this by breaking up sediment from the sea-bed and transporting and depositing it on top of reefs. ${ }^{71}$ This has caused the destruction of several reefs and extensive damage to the surrounding marine life. ${ }^{72}$ Although other states have expanded the islands that they claim, the speed and scale of China's construction has distressed competing nations. ${ }^{73}$ As of 2016, China has constructed "port facilities, military buildings, and an airstrip on the islands, with recent imagery showing evidence of two more airstrips under construction." ${ }^{74}$ Although the Chinese were not the first to begin island construction in the Spratly Islands, its island building has been much quicker than similar efforts in the South China Sea. ${ }^{75}$

These island installations are intended to bolster China's claims in the Spratly Islands. ${ }^{76}$ The new islands allow China to control and exploit portions of the sea, exercise more control over fishing in the region, extract natural resources from the sea-bed, and fortify the Chinese's territorial claims. The Spratly Islands also enable continued Chinese air and sea patrols. ${ }^{77}$ One of the new islands is strategically significant because it has an airstrip long enough for planes, fighter jets, and large transport aircrafts to land. ${ }^{78}$ These are not the first airstrips in the region; every other country that occupies islands in the South China Sea operates their own airstrips,

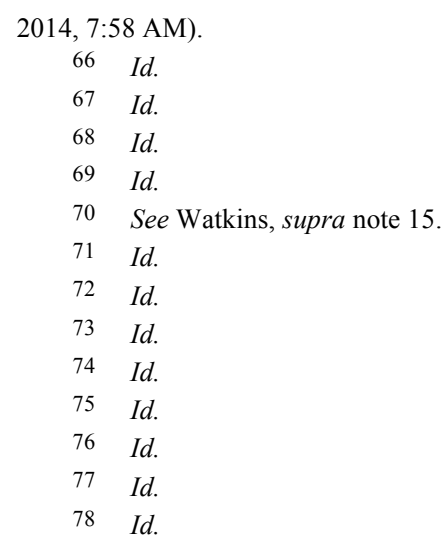


but China would be the first to have three airstrips in the area. ${ }^{79}$ By preserving the original buildings on the islands, China can assert that it is only expanding its former facilities, which is what the competing states have done on the islands that they occupy.

\section{B. ViETNAM's CLAimS}

Vietnam's claims to the Spratly Islands are based on discovery and occupation. ${ }^{80}$ Official Vietnamese documents assert that its ownership can be traced to 1650 , but these claims are largely unsupported. ${ }^{81}$ However, in 1816, Emperor Gia-long did claim governance over the islands, and an inaccurate 1838 Vietnamese map does present the Spratly Islands, named Van Ly Truong Sa, as Vietnamese territory. ${ }^{82}$

In the Sino-French Treaty of 1887 , the French protectorate declared Vietnam to be French territory, but the treaty avoids any mention of islands in the South China Sea. ${ }^{83}$ When France claimed the Spratly Islands in 1933, Vietnam did not protest the taking. ${ }^{84}$ And, at the 1951 San Francisco Peace Treaty, France signed the treaty relinquishing its claims over the islands with no attempt to reassert its sovereignty over them and with no reservations to the treaty. ${ }^{85}$ At this treaty's conference, Vietnam affirmed its sovereign control over the Spratly Islands, but this claim was immediately and strongly challenged by the statement of Premier Zhou Enlai, despite the fact that China was not represented at the conference because they were not invited. ${ }^{86}$ Vietnam argued that since its claim passed uncontested by conference members, there was universal recognition of its claim. $^{87}$

In 1956, when the Philippines first laid claims to the Spratly Islands, the Republic of South Vietnam protested, which modern-day Vietnam believes reaffirmed their ownership of the Spratly Islands. ${ }^{88}$ But, the government of North Vietnam supported Chinese ownership of the Spratly Islands. ${ }^{89}$ By 1973, the Republic of South Vietnam had incorporated eleven

$\begin{array}{ll}79 & I d . \\ 80 & \text { See Cordner, supra note } 32 \text {, at } 65 . \\ 81 & I d . \\ 82 & I d . \\ 83 & I d . \\ 84 & I d . \\ 85 & I d . \text { at } 66 . \\ 86 & I d . \text { at } 65 . \\ 87 & I d . \text { at } 66 . \\ 88 & I d . \\ 89 & I d .\end{array}$


of the islands and occupied five of the islands. ${ }^{90}$ And, by 1975, upon Vietnamese reunification, the government reasserted its claims over the entire island group despite North Vietnam's previous support of China's claims. $^{91}$ Since then, the "Vietnamese have continued to maintain precarious garrisons on up to twenty-two features of the Spratlys, supporting a claim to effective occupation of part of the Spratly archipelago since 1973."

In January 2016, Vietnam formally accused China of violating its sovereignty because China landed a plane on an airstrip on one of its new islands. ${ }^{93}$ This new island lies in an area that both China and Vietnam claim sovereignty over. ${ }^{94}$ According to newspaper sources, "Vietnam reportedly logged 46 such incidents - which the country says endangers air safety and violates its sovereignty — in just one week." 95 The Foreign Minister of Vietnam asserted that the airfield was built illegally in Vietnam's territory. ${ }^{96}$ China's Foreign Minister answered these assertions, claiming that the flight to the new airfield was completely within China's sovereignty. ${ }^{97}$ In response to this, Vietnam has sent letters of protest to China and the International Civil Aviation Organization ("ICAO"). ${ }^{98}$ The Civil Aviation Authority of Vietnam also sent letters to the ICAO, several other aviation bodies, and more than one hundred international carriers, asking them to implement measures to prevent China from continuing these actions and urging them to protest China's actions. ${ }^{99}$ Vietnam expects the ICAO to issue warnings to China because it is responsible for international civil aviation activities. ${ }^{100}$

\section{The Philippines' Claims}

The Philippines' claim to the majority of the islands in the Spratly

$90 \quad I d$.

91 Id. at 65.

92 Id. at 66.

93 See Reuters, Vietnam Protests After China Lands Plane on Disputed Spratly Islands, GUARDIAN (Jan. 3, 2016, 12:37 AM), https://www.theguardian.com/world/2016/jan/03/vietnamprotests-after-china-lands-plane-on-disputed-spratly-islands.

94 Id.

95 Sneha Shankar, Vietnam Asks International Aviation Community to Condemn China Over Spratly Island Flights, INT'L BUS. TIMES (Jan. 10, 2016, 8:09 AM), http://www.ibtimes.com/vietnamasks-international-aviation-community-condemn-china-over-spratly-islands-2258169.

96 See Reuters, supra note 93.

97 Id.

98 See Shankar, supra note 95.

99 Id.

$100 \quad I d$ 
Island group stems from the discovery of terra nullius by Tomas Cloma, a Filipino businessman and lawyer. Cloma claims to have discovered the islands in $1947 .^{101}$ And, in 1956, he proclaimed the islands as a new state named Kalayaan and established himself as the chairman of the Supreme Council of the new state. ${ }^{102} \mathrm{He}$ established small settlements on these islands, but remained physically present on them for only a few months. ${ }^{103}$ Although the Filipino government remained ambiguous about Cloma's claims, it did assert that the Kalayaan state was terra nullius and separate from the Spratly Islands. ${ }^{104}$

In 1974, the Philippines received ownership of the Kalayaan state from Cloma. ${ }^{105}$ In 1978, the Philippines' President declared that the Kalayaan state was part of Filipino sovereign territory. ${ }^{106} \mathrm{He}$ also declared a 200nautical mile EEZ extending from the territorial sea baseline. ${ }^{107}$ Currently, the Philippines occupies eight islands in the Spratly Islands. ${ }^{108}$

In 2013, the Philippines took legal action against China and filed a complaint with the PCA in order to initiate arbitral proceedings against China for breaching its sovereignty in the South China Sea. ${ }^{109}$ While China immediately rejected the jurisdiction of the Tribunal, the PCA originally found that it had jurisdiction over the majority of the claims that the Philippines brought against China, but did not make a decision about the rest of the claims the Philippines made until its final Award was issued. ${ }^{110}$

Most recently, China has demanded all Filipino military forces withdraw from one of the disputed islands in the Spratly Island group. ${ }^{111}$ The Foreign Minister of China stated, "We again call on the Philippines to withdraw their personnel and construction from the islands which the Filipino side illegally occupied, refrain from actions that harm regional peace and stability, and do not facilitate Chinese-Filipino relations." 112 This was in response to peaceful, Filipino student protesters, who were present

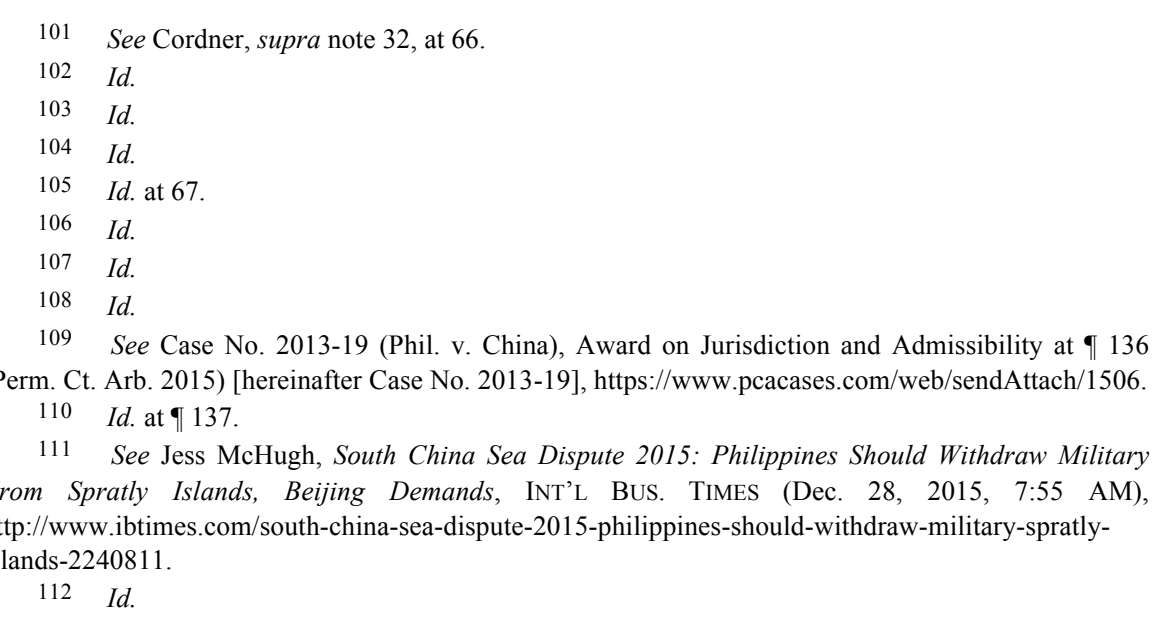


on one of the largest islands in the Spratly Island group for three days, demonstrating to condemn China's continuing construction of new islands and to assert the Philippine's absolute right to the islands. ${ }^{113}$

On June 30, 2016, the newly elected Rodrigo Duterte assumed the presidency of the Philippines. ${ }^{114}$ President Duterte, described as a "maverick," "controversial," and "an executioner who would bring terror to the Philippines," campaigned on very forthright statements about the South China Sea, including that "he would sail to the disputed islands and plant the Philippine flag there."115 As a political outsider and skeptic of the United States' involvement, President Duterte has expressed a willingness to negotiate with China over the disputed islands, which is a very different approach from the previous administration, which filed for arbitration over the matter. ${ }^{116}$ The Philippines will soon be faced with the choice of either maintaining its alliance with the United States or making deals with China; a decision which will significantly impact all states currently disputing the Spratly Islands.

\section{Malaysia AND BRUnei's Claims}

Both Malaysia and Brunei's claims to the southern portion of the Spratly Islands are based on their geographic proximity to the islands. Under UNCLOS Article 76, the legal continental shelf is the "submerged prolongation of the land mass of the coastal State, [which] consists of the sea-bed and subsoil of the shelf, the slope, and the rise."117 UNCLOS does not reference or have any provision for land that rises above sea level. ${ }^{118}$ So, under UNCLOS, none of the states contesting ownership of the islands or the surrounding waters, can claim the continental shelf of cays, islets, atolls, or other similar above sea level features. Furthermore, under UNCLOS, the claiming state does not need to demonstrate any form of control over the continental shelf to prove its ownership. ${ }^{119}$

Malaysia, in its claims, has invoked UNCLOS; specifically, the

113 Id

114 Shirley Escalante, Rodrigo Duterte Officially Declared Philippines Election Winner; Leni Robredo Wins VP Race, ABC NEWs, http://www.abc.net.au/news/2016-05-28/rodrigo-duterte-officiallydeclared-philippines-election-winner/7455682 (updated May 27, 2016, 8:58 PM).

115 Philippines Election: Maverick Rodrigo Duterte Wins Presidency, BBC NEWS (May 10, 2016), http://www.bbc.com/news/world-asia-36253612.

116 Wyatt Olson, South China Sea Has Become Flashpoint Between American Status Quo and Chinese Naval Ambitions, STARS \& STRIPES (Oct. 2, 2016), https://www.stripes.com/news/south-chinasea-has-become-flashpoint-between-american-status-quo-and-chinese-naval-ambitions-1.432079.

117 United Nations Convention on the Law of the Sea, supra note 16, at art. 76.

118 See Cordner, supra note 32, at 67.

119 See United Nations Convention on the Law of the Sea, supra note 16, at art. 77. 
provisions that address the continental shelf and its promulgated Continental Shelf Act of 1966, which is modeled after the 1958 Geneva Convention on the Continental Shelf. ${ }^{120}$ Malaysia's claims coincided with the publication of the Malaysian Map of 1979, which defined Malaysia's continental shelf area. ${ }^{121}$ Malaysia also claimed an EEZ in 1984, but it has not yet published an official map outlining the coordinates of these delimitations or their baselines. ${ }^{122}$ Malaysia has also "declared sovereign jurisdiction over all islands and atolls on the prescribed continental shelf on the theory that the 1958 Geneva Conventions on territorial waters and continental shelf boundaries and LOSC [UNCLOS] support such an assertion." ${ }^{23}$ But, Malaysia is also asserting a twelve-nautical-mile territorial sea from Swallow Reef and Amboyna Cay, which are above sea level at high tide. ${ }^{124}$ Since 1983, Malaysia has stationed troops on three of the islands that it claims, and it has reportedly built a holiday resort on one of the islands. ${ }^{125}$

Brunei, the state with the smallest jurisdictional claim, bases its claims upon its continental shelf delimitation, which was first established by Britain in 1954. ${ }^{126}$ Brunei's claim stems from UNCLOS's continental shelf provisions and the Territorial Waters of Brunei Act from 1982. ${ }^{127}$ It claims a "12-mile territorial sea; a 200-mile EEZ; and a continental shelf to the outer edge of the continental margin, or to 200 nautical miles where the outer edge does not extend up to that distance."128 Brunei does not claim territorial sovereignty over any of the disputed islands; rather, its claims are for maritime jurisdiction throughout its EEZ. ${ }^{129}$ Essentially, Brunei is only asking for its complete jurisdiction throughout the EEZ that UNCLOS guarantees. Because none of the islands lie within this zone, it is not asserting sovereignty over any of the islands.

In 1980, Britain and Malaysia entered into discussions concerning the maritime delimitation of their adjacent maritime boundaries. ${ }^{130}$ This discussion was continued in 1984, after Brunei's independence from

120 See Cordner, supra note 32 , at 66.

121 Id.

122 Id.; see also J. ASHLEY ROACH, MALAYSIA AND BRUNEI: AN ANALYSIS OF THEIR CLAIMS IN THE SOUTH CHINA SEA 2 (2014), https://www.cna.org/CNA_files/PDF/IOP-2014-U-008434.pdf.

123 Cordner, supra note 32 , at 67.

124 Id.

125 Id.

126 See Cordner, supra note 32, at 68; see also DANIEL J. DZUREK, Maritime Briefing: THE SPRATLY ISLANDS DiSPUTE: WHO's ON FIRST 45 (Clive Schofield ed., vol. 2 no. 1, 1996).

127 See Cordner, supra note 32, at 67.

128 ROACH, supra note 122 , at 35.

129 See DZUREK, supra note 126, at 45.

130 See Cordner, supra note 32, at 67. 
Britain. ${ }^{131}$ By March of 2009, after many years of bilateral discussions between Brunei and Malaysia, the leaders of both states signed an Exchange of Letters. ${ }^{132}$ The Exchange of Letters included, among other decisions, the final delimitation of the maritime boundaries and the permanent right of Malaysians to cross through Brunei's maritime zones. ${ }^{133}$ The agreement over the maritime boundaries also solidified the previously contested delimitation of the territorial sea, the continental shelf, and the EEZs of both states. ${ }^{134}$ But, neither state has publicly announced or published these maritime boundaries, and Articles 75(2) and 84(2) of UNCLOS require publication. ${ }^{135}$

Recently, Malaysia granted Chinese naval ships access to use one of its ports near the Philippines and the Spratly Islands as a stopover location. ${ }^{136}$ Analysts claim this was done in an attempt to maintain peace in the South China Sea and avoid taking sides in the dispute. ${ }^{137}$ Scholars claim this act is a gesture of neutrality because that port was already open to the United States, France, and other states. ${ }^{138}$ Malaysia has been cautious to confront China, unlike the Philippines and Vietnam, even in the face of its disapproval of Chinese naval and coastguard ships entering contested waters and its fishermen's resentment of Chinese competitors exploiting the area. ${ }^{139}$ A military analyst argues that this action demonstrates China's willingness to cooperate with smaller nations in the disputed area, and is beneficial to Malaysia because stronger relations with China will give it more confidence when dealing with the Philippines and Vietnam in the contested region. ${ }^{140}$ Brunei has been silent with regard to states' recent developments in the Spratly Island group. ${ }^{141}$

$131 \quad I d$.

132 See generally ROACH, supra note 122.

133 See ROACH, supra note 122, at 46.

134 Id

135 See ROACH, supra note 122, at 13; see also United Nations Convention on the Law of the Sea, supra note 16 , at art. 75(2), 84(2).

136 See PLA Navy Gains Use of Port in Malaysia Close to Spratly Islands, SoUTH CHINA Morning Post (Nov. 21, 2015, 12:23 AM), http://www.scmp.com/news/china/diplomacydefence/article/1881300/pla-navy-gains-use-port-malaysia.

137 Id.

138 Id.

139 Id

140 Id.

141 See DZUREK, supra note 126 , at 45. 


\section{ANALYSIS}

Because all five competing states have ratified UNCLOS, they have implicitly agreed to settle the dispute arising from its interpretation through international arbitration. UNCLOS gives jurisdiction to the ITLS, the ICJ, or the PCA, and the ICJ and the PCA have previously decided cases interpreting UNCLOS. ${ }^{142}$ Analyzing past cases from these two courts assists in determining how the courts evaluate and apply the laws and how they would likely weigh the strengths and weaknesses of each state's claim to the Spratly Islands. Per the existing state of the law, none of the states competing for sovereignty over the Spratly Islands have perfect claims. And, because of China's constant refusal to work through international laws, any decision made by the ICJ or PCA would likely be rejected and ignored by it. The best decision for all states involved would be to work through a Joint Development Zone Agreement, similar to the one established by Nigeria and Sao Tome and Principe. The best chance for this to work would be if China, Vietnam, the Philippines, Malaysia, and Brunei worked together in developing this agreement without any intervention from third party states, like the United States or nongovernmental organizations.

\section{A. INDONESIA V. MALAYSIA}

In 2002, the ICJ held, in a sixteen to one decision, that sovereignty over the Ligitan and Sipadan Islands belonged to Malaysia and not to Indonesia. ${ }^{143}$ Although decisions by the ICJ are typically made by a panel of 15 judges, in this particular case, there were two supplemental ad hoc judges. ${ }^{144}$ Each party had the opportunity to choose an ad hoc judge to sit in the case because none of the elected judges were from either party's nationality. ${ }^{145}$

The first issue the court considered was whether there had been valid treaties that decided whether either state could claim sovereignty over the islands. ${ }^{146}$ Claims based on treaty law are normally very persuasive to the ICJ because treaties are binding on parties that have ratified them, and because Article 38 of the ICJ Statute requires the court to consider treaties

142 See generally United Nations Convention on the Law of the Sea, supra note 16.

143 See Sovereignty Over Pulau Ligitan and Pulau Sipadan (Indon. v. Malay.), Judgment, 2002 I.C.J. Rep. 625 (Dec. 17).

144 Id. at 910.

145 Id.

$146 \quad I d$. 
when making decisions. ${ }^{147}$

In Indonesia v. Malaysia, Indonesia's claims to the islands stemmed from the 1891 Convention between Great Britain and the Netherlands. The ICJ examined the 1891 Convention, the record of negotiations, the subsequent conduct of the parties to the 1891 Convention, and the maps submitted by both states. ${ }^{148}$ It concluded that the object and purpose of the 1891 Convention was not to determine sovereignty over the islands east of the line of possession, and therefore did not give Indonesia a title on which it could claim the Ligitan and Sipadan islands. ${ }^{149}$

Along with treaty law, the court considered uti possidetis. ${ }^{150}$ The doctrine states that uti possidetis prevails over competing claims based on occupation. ${ }^{151}$ These types of claims can pose problems, as they did in this case, because administrative colonial borders are typically drawn vaguely. ${ }^{152}$ The ICJ considered whether Indonesia or Malaysia gained title to Ligitan and Sipadan by succession and rejected both states' claims to $u t i$ possidetis. ${ }^{153}$ It rejected Indonesia's claim that it retained title to the islands as successor to the Netherlands and also rejected Malaysia's claim that it gained sovereignty over the islands from the Sultan of Sulu. ${ }^{154}$ These claims were rejected because the documents, which transferred ownership of the islands between the states, never mentioned the islands; the claiming states never acted as if the islands were part of their territory; and the maps and treaties were generally too vague to draw any solid conclusions. ${ }^{155}$ The ICJ decided that if there were no valid treaties and uti possidetis did not apply, the next question would be whether effectivités ${ }^{156}$ could be applied to determine which state had the stronger legal basis to its claims. ${ }^{157}$

A claim based on effectivités, or effective control, is that a state or group has "uncontested administration of the land and its resident

147 See generally id.

148 Id. at 17.

149 Id. at 950.

150 Id. at 90. "Uti Possidetis is a Latin term which means 'as you possess." Uti Possidetis, USLEGAL, https://definitions.uslegal.com/u/uti-possidetis/ (last visited Mar. 1, 2017). Uti Possidetis is a doctrine through which states that recently gained their independence can inherit the pre-independence administrative boundaries created by their former colonizers.

151 See Bryan Taylor Sumner, Note, Territorial Disputes at the International Court of Justice, 53 DUKE L.J. 1779, 1790 (2004).

152 Id. at 1791.

153 See Sovereignty Over Pulau Ligitan and Pulau Sipadan (Indon./Malay.), Judgement, 2002 I.C.J. Rep. 625, $\uparrow 99$ (Dec. 17).

$154 \quad I d$. at 9119.

155 Id. at 122.

156 A principle of effective control. See id. at $\uparrow 128$.

157 Id. at 137. 
population."158 To establish effectivités, states need to prove two elements: 1) the intention and will to act as a sovereign and 2) some actual exercise or display of such authority. ${ }^{159}$ The court further stated that "in many cases the tribunal has been satisfied with very little in the way of the actual exercise of sovereign rights, provided that the other State could not make out a superior claim." "It It also specifically noted that "in the case of very small islands which are uninhabited or not permanently inhabited, [like the Spratly islands] which have been of little economic importance, effectivités will indeed generally be scarce."161 The court continued by establishing that "activities by private persons cannot be seen as effectivités if they do not take place on the basis of official regulations or under governmental authority." $" 162$ It also observed that it could not take into consideration acts that took place after the date the dispute between the parties was solidified, unless those acts were a normal continuation of previous acts and were not done for the purpose of improving the legal position of the party taking the actions. ${ }^{163}$ Many scholars consider effectivités the most important factor in establishing a strong territorial claim. ${ }^{164}$

The court in Indonesia v. Malaysia analyzed activities that evidenced an actual, continued exercise of authority over the islands. ${ }^{165}$ The ICJ concluded that Malaysia had title to Ligitan and Sipadan on the basis of effectivités because Malaysia had taken actions including the regulation and control of turtle eggs from the islands and the creation of a bird reserve on Sipadan. ${ }^{166}$ The court considered these actions as regulatory and administrative assertions of authority over the contested territory and, although few in number, they spanned a lengthy period of time and demonstrated an intention to exercise state functions on the two islands. ${ }^{167}$ Indonesia's claims failed mostly because it did not demonstrate state action over the islands, and its claims were severely weakened by an Indonesian waters act map, which defined its archipelagic baselines, that failed to include or even mention the Ligitan and Sipadan islands. ${ }^{168}$ The court did

158 Sumner, supra note 151, at 1787.

159 See Sovereignty Over Pulau Ligitan and Pulau Sipadan (Indon./Malay.), Judgement, 2002 I.C.J. Rep. 625, 129 (Dec. 17).

$160 \quad$ Id. at 9131.

$161 \quad I d$. at $\uparrow 135$.

162 Id. at 9139.

163 Id. at 1140.

164 See Sumner, supra note 151, at 1787.

165 See Sovereignty Over Pulau Ligitan and Pulau Sipadan (Indon./Malay.), Judgement, 2002 I.C.J. Rep. 625, ๆ 127 (Dec. 17).

166 Id. at 9129.

167 Id. at 9137.

168 Id. at 140. 
not make a decision regarding the territorial waters or the maritime borders. ${ }^{169}$

\section{B. The Palmas Case}

In 1928, the PCA arbitrated a territorial and maritime dispute over the Island of Palmas between the United States and the Netherlands. ${ }^{170}$ The United States and the Netherlands both claimed sovereignty over the Palmas islands, located between the Philippines and the Dutch East Islands. ${ }^{171}$ The United States claimed that Spain originally held sovereign title to the islands, and then ceded title to the United States through the Treaty of Paris. ${ }^{172}$ They also claimed title through contiguity, or geographical proximity, between the Philippines and the island. ${ }^{173}$ The Netherlands claimed sovereignty through their continuous display of authority over the island. ${ }^{174}$

The PCA determined that discovery of a piece of land only resulted in inchoate title and was not sufficient to establish sovereignty. ${ }^{175}$ Sovereignty through inchoate title would only be sufficient if it was followed by effective occupation or a continuous display of authority. ${ }^{176}$ But, peaceful and continuous displays of sovereignty, like occupation and presence, could be as good as having title. ${ }^{177}$ Because the territorial sovereignty of the Netherlands on the Island of Palmas went uncontested from 1700 to 1906, and the Netherlands maintained effective control of the island throughout these years, its claim was stronger than the United States' claim through inchoate title. ${ }^{178}$

\section{Indonesia V. Malaysia Standard and the Palmas Case STANDARD}

Both China and Vietnam have attempted to use treaty law to justify their claims to the Spratly Islands, but neither of their claims would likely

\footnotetext{
169 Id. at 9139.

170 See generally Island of Palmas (Neth. v. U.S.), Special Agreement, 2 R.I.A.A. 829 (Perm. Ct. Arb. 1928).

171 Id. at 844.

$172 I d$.

173 Id. at 856.

174 Id. at 857.

175 Id

176 Id. at 860.

177 Id. at 863

178 Id. at 864.
} 
succeed at the ICJ. The Sino-French Treaty of 1887, like the 1891 Convention between Great Britain and the Netherlands, was not written to determine sovereignty over the islands east of the line of demarcation, but rather to establish Vietnam as a French protectorate and solidify France's claims in the west. The ICJ would likely conclude that the treaty did not give China title of the Spratly Islands, like the 1891 Convention did not give Indonesia title of the Ligitian and Sipadan Islands, because the Spratly Islands are neither mentioned nor named; the north, south, and east lines of demarcation are not included; and the French and Chinese interpretations of the Treaty differ. All of these factors indicate that the object and purpose of the Sino-French Treaty of 1887 was not to determine sovereignty over the disputed islands. Furthermore, on December 25, 2000, China and Vietnam both agreed that the Sino-French Treaty of 1887 did not set the maritime boundaries between them. ${ }^{179}$ However, they did sign the Agreement on Fishery Cooperation in the Gulf of Tunkin and the Agreement on Maritime Boundary Delimitation in the Gulf of Tunkin. ${ }^{180}$

Both China and Vietnam also base part of their claims to the Spratly Islands on the San Francisco Peace Treaty. In the San Francisco Peace Treaty, Japan formally renounced all rights, titles, and claims to the Spratly Islands. France also signed the treaty without reservation, and made no attempt to reassert its past claims over the islands. The purpose of this treaty was not to grant title of the Spratly Islands to any state. This is evidenced through the language of the treaty, which did not name a successor to the islands. It is also evidenced in that, after Japan relinquished its claims, both China and Vietnam formally asserted that the Spratly Islands belonged to them. Since neither of the treaties gave sovereign control over the islands to any state, the ICJ would not likely resolve this dispute using treaty law. Furthermore, since the ICJ seems to be strict in honoring the object and purpose of the treaties it interprets, neither treaty would likely be found to have conveyed title to either China or Vietnam.

Vietnam's claims under uti possidetis would likely be unsuccessful. Vietnam claims title by French succession because France did occupy some of the islands in the South China Sea in the early 1930s. However, the statements made by Gerard Chesnel, the French Consulate in Hong Kong, effectively nullified these claims. ${ }^{181}$ On March 22, 1977, he stated that the

179 See Interview by Cheng Jieshe with Jianguo Xiao, Official, Legal Section of China's Foreign Ministry (July 28, 2004).

180 Id.

181 See Junwu Pan, Regional Focus \& Controversy: Maritime and Territorial Dispute in the South China Sea: Territorial Dispute between China and Vietnam in the South China Sea: A Chinese Lawyer's Perspective, JEAIL, Spring 2012, at 213. 
agreement that officially recognized Vietnam's independence did not mention the Spratly Islands as Vietnam's territory. ${ }^{182}$ Because the ICJ is very strict in enforcing the object and purpose of the treaties it has to interpret, the agreement that officially recognized Vietnam's independence would not be used to recognize Vietnam's claims over the Spratly Islands.

In Indonesia v. Malaysia and in the Palmas Case, the ICJ and the PCA used similar concepts to determine the strengths of a state's claims. In both cases, discovery was not sufficient to make a valid claim of sovereignty to a piece of land. Rather, the ICJ looked to effectivités, and, the PCA looked to 1) territorial sovereignty over the disputed land and 2) maintained effective control over the disputed land. The state actions necessary to satisfy effective control under these two separate criteria are very similar.

While China's claims that the islands were terra nullis prior to its discovery is valid, the subsequent history of the islands makes China's ancient claims to the entire island group unconvincing. First, despite that China may have discovered the islands, a fact that has yet to be clearly established, throughout history it failed to maintain effective control of the islands it occupied. This is evident from the fact that both Japan and France had control of the islands for a number of years. China has also failed to show that any of the fishermen, explorers, or cartographers maintained a presence on the islands on the basis of official regulation or government authority, as is required by the ICJ. Furthermore, while inchoate title could be received through discovery, per the PCA, it would only be sufficient if followed by effective occupation or a continuous display of authority, which, as mentioned above, China has failed to demonstrate.

Second, China's ancient claims are insufficient to evince effective control, under the Indonesia v. Malaysia standard or the Palmas Case standard, because the Chinese government did not exert uncontested administration of the Spratly Islands. Rather, Chinese fishermen occasionally visited the islands and used the surrounding waters. The acts of these fisherman cannot be used to establish effective control because they are not the acts of sovereigns and were not used to display authority or control. Furthermore, the actions of the explorers and cartographers cannot be used to establish effective control either. While the cartographers and explorers who briefly explored the region could be seen as acting under the direction of China, their actions do not evince effective control since their presence in the South China Sea was only temporary.

Third, the 1928 Chinese Government Report portrays the southernmost delimitation of Chinese territory as the Parcel Islands, ${ }^{183}$ and makes no

182 Id

183 The Parcel Islands lie north of the Spratly Islands. See Watkins, supra note 15. 
mention of the Spratly Islands, which would severely weaken China's claims of effective control like the Indonesian waters act map, which weakened Indonesia's claim because it failed to include, or even mention, the Ligitan and Sipadan islands. This would weaken the claim of effective control because it does not portray China as having the intention to act as sovereign over the islands since the islands are not even mentioned on its map. Because effective control cannot be based on activities by private persons not acting on behalf of the government or official regulation, and effective control has to be maintained, China would not be able to establish effective control since ancient times.

Vietnam's historical claims of effective control are also weak. Throughout Vietnam's history, there have been significant gaps in its control over the Spratly Islands. This is exemplified during the time that Vietnam was occupied by France, which weakens its claims to the Spratly Islands since it could not maintain continuous control while it was being governed by another country. First, France has explicitly denied ceding the Spratly Islands to Vietnam. Second, although South Vietnam asserted its claims to the Spratly Islands in 1956 and 1958, North Vietnam expressed its support of China's claims, not South Vietnam's claims. Third, modern day Vietnam is a successor to North Vietnam; so, North Vietnam's statements in support of China's claims to the Spratly Islands are more binding than South Vietnam's 1950s claims, even though in 1975 modern day Vietnam reasserted South Vietnam's claims. Because of these significant gaps, Vietnam did not maintain effective control over the Spratly Islands, and, as portrayed by North Vietnam's support of China's claims, it would not be seen to have historically had the intention to act as sovereign over the islands. Vietnam's historical claims will not likely satisfy the Indonesia $v$. Malaysia standard or the Palmas Case standard for effective control.

The Philippines' historical claims are largely unsupported by international law. The ICJ in Indonesia $v$. Malaysia established that activities by private persons cannot be seen to establish effective control if they are not initiated by a governmental authority or official regulation. Even if Cloma claims to have discovered the islands in 1947, his actions and claims cannot be imputed to the Philippines because he was clearly not acting with the Philippines' authority. This is evident because he claimed the islands for himself and established himself as the chairman of the Supreme Council of Kalayaan. Furthermore, it was not until 1974, twentyseven years after he allegedly discovered the islands, that the Philippines claimed to have received ownership from him.

Although none of the states have strong historical claims, their recent actions over the Spratly Islands are much more indicative of effective control. However, none of these actions can be used by the states to 
establish effective control because they take place after the date on which the dispute between the states crystallized. In Indonesia v. Malaysia, the court found that the dispute crystallized in 1969, the year that the states asserted conflicting claims to the Ligitan and Sipadan islands. With respect to finding the date on which the dispute over the Spratly Islands began, it would be much more difficult to establish a starting date because some of the claims the states have made are very deeply rooted in historic evidence. When determining the date that the dispute crystallized, the courts would likely look at the strong protests the states made when a competing state claimed sovereignty over the islands. For example, when China strongly protested the French government for taking the islands in 1932 and during the 1951 San Francisco Peace Treaty when the Premier of China strongly challenged Vietnam's claims to the islands. Courts would also likely look at the dates the states began occupying the islands. For these reasons, a court would likely determine that by 1951, Vietnam and China officially had competing claims to the islands; by 1956, the Philippines had officially asserted conflicting claims to these islands; and by 1960, Brunei and Malaysia had announced their claims to the Spratly Islands. Any actions taken after these dates, unless they were a normal continuation of previous acts and were not done for the purpose of improving the legal position of the party taking the actions, would not be used to establish effective control.

The majority of the Spratly Islands in the South China Sea are currently occupied by a state. China, Vietnam, the Philippines, and Malaysia are all currently occupying at least a few islands. China's island construction in the South China Sea is unprecedented. The construction of port facilities, military buildings, and airstrips on the islands are undoubtedly the acts of China as a sovereign state, and it demonstrates authority and control over the islands that China occupies. The new islands enable China to maintain effective control not only on the islands it occupies, but also of the surrounding waters and sea-beds. Furthermore, the military confrontations between China and Vietnam in the South China Sea demonstrate both the intention to act as a sovereign over the Spratly Islands and an actual exercise by the government to establish and maintain sovereign control over the islands that they claim. However, none of this would be considered by a court when determining if China has demonstrated effective control. This is because these actions occurred significantly after the four other competing states asserted their claims to the islands, and these actions are not a continuation of the acts of the Chinese fishermen and cartographers that China used as evidence to bolster its claims. Furthermore, it is highly likely that a court would see China's island building as an attempt to solidify its claims in the South China Sea, and, as stated in Indonesia v. Malaysia, acts done for the purpose of improving the legal position of the party taking the actions will not be used 
to establish effective control.

China is not the only state that would have this problem. As of 2015, Vietnam has also been constructing and expanding the borders of the islands that it occupies. ${ }^{184}$ It was the first state to build an airstrip on one of the islands that it occupies. ${ }^{185}$ The Philippines has also recently engaged in island construction and also has an airstrip on one of the islands it occupies. As of 2016, there were Filipino military forces on a few of the contested islands. Student protestors were also recently present on one of the islands, trying to bolster the Philippines claims to the Spratly Islands and condemn China's continuous island building. Malaysia also has an airstrip on one of the islands that it occupies.

A court would not use any of these actions as evidence of effective control by any of these states because they all occurred after the states asserted the conflicting claims to the islands. Furthermore, it is highly likely that a court would see these actions as an attempt to solidify the states' claims in the South China Sea. The Philippines specifically runs against an additional problem since the student protestors on the islands would not buttress effective control because the students are private individuals and their acts would not be imputed to the Filipino government.

\section{THE PHILIPPINES V. THE REPUBLIC OF CHINA}

In 2013, the Philippines filed a complaint with the PCA to institute arbitral proceedings against China. ${ }^{186}$ It invoked Article 287 of UNCLOS and unilaterally initiated proceedings with the PCA. ${ }^{187}$ This dispute concerned China's claims over the maritime jurisdiction of the Philippines in the South China Sea. ${ }^{188}$ Essentially, the Philippines asked the PCA to make three findings: 1) that the "nine-dash-line" contradicts UNCLOS and that UNCLOS should be the only basis for maritime jurisdiction and sovereignty; 2) that contested maritime formations ${ }^{189}$ are not entitled to the adjoining continental shelf or the 200-mile EEZ; and 3) that China's actions and behaviors in the South China Sea violate its obligations under

184 See Tan Qiuyi, Vietnam Defends Construction in Disputed South China Sea, CHANNEl News ASIA (May 14, 2015, 8:32 PM).

185 See Airpower in the South China Sea, CTR. FOR STRATEGIC \& INT’L STUD. (July 29, 2015), https://amti.csis.org/airstrips-scs/.

186 See generally Case No. 2013-19, supra note 109.

187 See Christopher Mirasola, A Shifting Tide in the South China Sea: The Permanent Court of Arbitration Declares Jurisdiction, HARV. INT'L L.J. (Nov. 9, 2015), http://www.harvardilj.org/2015/11/ a-shifting-tide-in-the-south-china-sea-the-permanent-court-of-arbitration-declares-jurisdiction/.

188 See generally Case No. 2013-19, supra note 109.

189 Including reefs, atolls, isles, islets, etc. 
UNCLOS and interfere with the Philippines' sovereignty. ${ }^{190}$ On July 12 , 2016, the PCA issued its unanimous and final Award, concluding the case. ${ }^{191}$

Although the PCA did find that it had jurisdiction over the dispute as per the Articles of UNCLOS, China rejected, and has continued to reject, the authority of the Tribunal and refused to participate in the arbitration. ${ }^{192}$ China was absent on the day of the hearing on jurisdiction, but it did publish a position paper outlining its legal claims to the islands and contesting all the claims made by the Philippines. ${ }^{193}$ Although China refused to participate in the proceedings, the PCA used China's position paper in its decision-making and cited to the position paper in its Award on Jurisdiction and Admissibility and in its final Award. ${ }^{194}$ In its position paper, China responded that without first determining which state has territorial sovereignty over the islands, the PCA cannot determine the extent of China's or the Philippines' maritime claims. ${ }^{195}$ China also correctly stressed that tribunals established under Article 287 and Annex VII of UNCLOS, like the PCA, have no jurisdiction over territorial disputes. ${ }^{196}$ China expressed that, for the PCA to resolve the maritime dispute, it would have to also make territorial determinations, which would contravene the "general principles of international law and international jurisprudence on the settlement of international maritime disputes." ${ }^{\text {"197 }}$ Moreover, China argued that through the Consultation on the South China Sea and on Other Areas of Cooperation, issued August 10, 1995; the Declaration on the Conduct of Parties in the South China Sea, agreed upon in 2002; and the Treaty of Amity and Cooperation in Southeast Asia, all signatory states agreed to resolve all disputes through negotiations and therefore excluded any means of third-party settlement. ${ }^{198}$

Ultimately, on October 29, 2015, the PCA unanimously decided that it had jurisdiction over seven of the fifteen claims initiated by the Philippines. ${ }^{199}$ It reserved judgment on the other eight claims, ${ }^{200}$ and, in its

190 See Mirasola, supra note 187.

191 See generally Case No. 2013-19, supra note 109.

192 See Ministry of Foreign Affairs of the People's Republic of China, supra note 18; see generally United Nations Convention on the Law of the Sea, supra note 16.

193 See Ministry of Foreign Affairs of the People's Republic of China, supra note 18; see generally United Nations Convention on the Law of the Sea, supra note 16.

194 See Ministry of Foreign Affairs of the People's Republic of China, supra note 18; see generally Case No. 2013-19, supra note 109.

195 See Ministry of Foreign Affairs of the People's Republic of China, supra note 18.

196 Id.

$197 I d$

198 See id.

199 See generally Case No. 2013-19, supra note 109; see also Mirasola, supra note 187. 
final Award, it unanimously decided that it had complete jurisdiction over all but two of the claims. ${ }^{201}$ Because neither China nor the Philippines opted for a specific type of dispute resolution when they ratified UNCLOS, the PCA found that the Philippines was justified in initiating proceedings with the PCA. The PCA also found that China's refusal to participate would not hinder the proceedings because "the absence of a party or failure of a party to defend its case shall not constitute a bar to the proceedings." 202

Although China was not present, the PCA claimed that it implemented procedural safeguards to protect China's rights. ${ }^{203}$ Normally, in determining whether a state abused process in initiating proceedings, the PCA will use the standard adopted in Article 294 at a defending state's request. This is the "blatant cases of abuse or harassment" standard. However, the PCA adopted a weaker standard when it determined whether the Philippines abused process in initiating these proceedings instead of the more rigorous standard established in Article 294 because China did not request it. ${ }^{204}$ The PCA also found that the bilateral and multilateral treaties and decisions entered into by China and the Philippines did not bar the PCA's jurisdiction because these documents did not represent a settlement between the parties, ${ }^{205}$ did not exclude other dispute resolution mechanisms, ${ }^{206}$ and do not require that the parties indefinitely pursue unsuccessful negotiations. ${ }^{207}$

In its final Award, the PCA was cautious to explicitly delimit the scope of its decision. The Tribunal recognized and honored China's 2006 declaration to UNCLOS that excluded maritime boundary delimitations from China's acceptance of compulsory dispute settlement. ${ }^{208}$ Because of this, the Tribunal stated that it would not make any rulings as to maritime delimitations. ${ }^{209}$ Furthermore, at the very beginning of the Award, the Tribunal also stated that it did not purport to make any rulings as to which state enjoys sovereignty over any land territory. ${ }^{210}$ It emphasized that none of the decisions were dependent on findings of sovereignty. ${ }^{211}$

200 Case No. 2013-19, supra note 109, at 934.

201 The PCA found that it had jurisdiction over submissions 1, 2, 3, 4, 5, 6, 7, 8, 9, 10, 11, 12, 13, and 14d but not 14a, 14b, 14c, or 15. Case No. 2013-19, supra note 109, at 1203(A)(8).

202 Mirasola, supra note 187.

203 See Case No. 2013-19, supra note 109, at 117.

204 See id. at 128.

205 Id.

206 Id. at 134.

207 Id. at $\uparrow 141$.

208 Id. at 6.

209 Id.

$210 \quad$ Id. at 9.

$211 \quad I d$. 
With respect to the Philippines' first claim - that the "nine-dash-line" contradicts UNCLOS and that UNCLOS should be the only basis for maritime jurisdiction and sovereignty - the Tribunal found in favor of the Philippines. The Award concluded that China's historic claims to the South China Seas could not survive to the extent that they contradicted the rights and obligations provided for in UNCLOS. ${ }^{212}$ The Award continued by explaining that although China made claims that there were navigators and fishermen on the islands, there was no evidence of control over the waters or resources. ${ }^{213}$ The PCA found no legal basis for China's historic claims to the seas within the "nine-dash-line" that would supersede UNCLOS. ${ }^{214}$

With respect to the Philippines' second claim - that contested maritime formations, including reefs, are not entitled to the adjoining continental shelf or the 200-mile EEZ-the PCA also found in favor of the Philippines. The PCA scrutinized the language of Article 121 of UNCLOS when reaching its decision, which states that

1) An island is a naturally formed area of land, surrounded by water, which is above water at high tide; 2) Except as provided for in paragraph 3 , the territorial sea, the contiguous zone, the exclusive economic zone and the continental shelf of an island are determined in accordance with the provisions of this Convention applicable to other land territory; and 3) Rocks which cannot sustain human habitation or economic life of their own shall have no exclusive economic zone or continental shelf. ${ }^{215}$

The PCA explained that in order to determine compliance with Article 121, the Tribunal must examine the objective capacity of a feature in its natural condition. ${ }^{216}$ Furthermore, whether a disputed feature is capable of sustaining human or economic life is decide on a case-by-case basis. ${ }^{217}$ However, the PCA decided that the presence of people dependent on outside support, and not reflective of the capacity of the features, would not be sufficient to satisfy the requirement that the rocks sustain human habitation or economic life. ${ }^{218}$ The Tribunal looked to China's historic claims and found that the alleged presence of fishermen and navigators on some of the islands was only transient, and therefore insufficient to

$\begin{array}{ll}212 & \text { Id. at } 277,278 . \\ 213 & I d . \\ 214 & I d . \\ 215 & I d \text { at } 9386 . \\ 216 & \text { Id. at } 905 . \\ 217 & \text { Id. at } 546 . \\ 218 & \text { Id. at } 547 .\end{array}$


establish inhabitation. ${ }^{219}$ Overall, the Tribunal held that none of the contested features claimed by China were capable of generating an EEZ and that some of these features were within the Philippines' EEZ.220

As to the Philippines' last claim - that China's actions and behaviors in the South China Sea violate its obligations under UNCLOS and interfere with the Philippines' sovereignty - the PCA also found in favor of the Philippines. Overall, the Tribunal found that China violated the Philippines' sovereignty in three ways. ${ }^{221}$ First, the Tribunal found China was interfering with the Philippines' fishing and petroleum exploration in the Philippines' EEZ. ${ }^{222}$ Second, China violated the Philippines' sovereignty by constructing artificial islands in the Philippines' EEZ. ${ }^{223}$ Last, the Tribunal believed that China violated the Philippines' sovereignty by failing to prevent Chinese fishermen from fishing in the Philippines' EEZ. $^{224}$

At a time when the majority of the world's super-powers are cynical about the enforcement power of international courts and tribunals, the PCA acted wisely in issuing a very cautious and limited decision when it granted its Award. From the very beginning, it expressly stated that it was not making any decisions as to territorial sovereignty or maritime delimitations. Furthermore, its decision concerning the "nine-dash-line" only reinforced the internationally recognized standard that treaty law prevails over all other claims. Also, the Tribunal's decision that the contested features could not generate an EEZ, was narrow in that it did not preclude any state from claiming sovereignty over the features, only from claiming the extended twelve-mile EEZ. Even its decision about China's aggressive island building in the South China Sea was limited to their island building within the Philippines' EEZ. Despite this narrow ruling, China has already stated that it would not abide by the decision issued by the Tribunal. ${ }^{225}$ Tensions have already escalated as, in August 2016, the Chinese Defense Minister called for preparations for a "people's war at sea." 226

China saw the Philippines submitting this dispute to the PCA as aggressive. ${ }^{227}$ China believed it was a decision that was tactically unwise and made in bad faith. The Philippines and China both previously agreed to

$\begin{array}{ll}219 & \text { Id. at } 618 . \\ 220 & \text { Id. at } 647 . \\ 221 & \text { Id. at } 1203(\mathrm{~B})(10)-(14) . \\ 222 & \text { Id. at } 1203(\mathrm{~B})(11) \\ 223 & \text { Id. at } 1203(\mathrm{~B})(14) . \\ 224 & \text { Id. at } 1203(\mathrm{~B})(10) . \\ 225 & \text { Olson, supra note } 116 . \\ 226 & \text { Id. } \\ 227 & \text { See Ministry of Foreign Affairs of the People's Republic of China, supra note } 18 .\end{array}$ 
the Declaration on the Conduct of Parties in the South China Sea, which stated that all parties involved in the dispute over the Spratly Islands would engage in peaceful negotiations amongst themselves and not refer the matter to a third party for dispute resolution. ${ }^{228}$ Since the Philippines violated the terms of the Declaration on the Conduct of Parties in the South China Sea by referring the case to the PCA, China has increased and strengthened its military presence in the disputed area. ${ }^{229}$ Also, current reports show that China has become increasingly aggressive in recent months in asserting its claim to the Spratly Islands. ${ }^{230}$ This is evidenced by their construction of new islands in the South China Sea, which contain "port facilities, military buildings and an airstrip... with recent imagery showing evidence of two more airstrips under construction." 231 China did not begin its massive dredging project on the reefs until late 2013, the same year the Philippines decided to submit its case for arbitration to the PCA. ${ }^{232}$ These newly built islands are an attempt to solidify its claims to the islands in the area and will enable the Chinese to continuously patrol the area by sea and air. ${ }^{233}$

The decision made by the PCA did not resolve the continuing dispute over the Spratly Islands. Most importantly, the Philippines and China were the only two parties to the case at the PCA. The decision not only left the territorial dispute unresolved as to those two parties, but it ignored the claims and problems that the other three states have been asserting. The Spratly Islands dispute is not a dispute that can be resolved by arbitration between only two of the five parties. Because of the multilateral nature of this dispute, a bilateral decision by a third party ignores the complexity of the ongoing situation and leaves the dispute largely unresolved. While bilateral agreements between states could work to help alleviate the tensions between China, Vietnam, the Philippines, Malaysia, and Brunei, one bilateral agreement will not resolve the problems that have arisen in the South China Sea. Although the PCA did not make determinations about which state has territorial rights to which islands, its decision undoubtedly affected the ever-evolving relationships between China, Vietnam, the Philippines, Brunei, and Malaysia.

228 See Declaration on the Conduct of Parties in the South China Sea, supra note 31, at section 4.

229 See Goldenziel, supra note 8.

230 See Shankar, supra note 95; Vishakha Sonawane, South China Sea Controversy: Chinese Military Aircraft Likely to Take Off From Spratly Islands in First Half of 2016, Ex-Army Official Says, INT'L BUS. TIMES (Jan. 8, 2016, 4:59 AM).

231 Watkins, supra note 15.

232 See China Says U.S. Warship's Spratly Islands Passage 'Illegal,' BBC News (Oct. 27, 2015), http://www.bbc.com/news/world-asia-china-34647651.

233 See Watkins, supra note 15. 


\section{E. UNITED STATES' INVOLVEMENT}

Recently, the United Sates has decided that its presence in the South China Sea is necessary to combat China's aggressive actions in the Spratly Islands. In 2013 and 2014, the United States conducted its Freedom of Navigation Program exercise against China in the South China Sea. ${ }^{234}$ The United States' Freedom of Navigation Program challenges what the United States considers to be "excessive claims" to the world's oceans and airspace. ${ }^{235}$ The program was created to promote international compliance with UNCLOS, even though the United States never ratified the treaty. ${ }^{236}$

The United States has confirmed that the USS Lassen, a guided-missile destroyer, has recently breached the twelve-nautical mile zone that China claims around two of the artificial islands that China occupies. ${ }^{237}$ However, the United States contends, "international maritime law allows countries to claim ownership of the twelve-nautical mile area surrounding natural islands, but does not allow nations to claim ownership of submerged features that have been raised by human intervention."238 So, China would not be able to assert the twelve-nautical mile area over islands that have been artificially built by man. While the United States has not officially endorsed the position of any of the states competing for sovereignty over the Spratly Islands, it has been very vocal in condemning China for its recent actions in the South China Sea. Even though all five states have engaged in islands building, the United States has isolated the Chinese artificial islands in performing the Freedom of Navigation Program operation.

The United States claims that its Freedom of Navigation Program was meant to challenge China's claims over the islands. ${ }^{239}$ Lu Kang, a spokesman for China's Foreign Ministry, responded by stating that China would

resolutely respond to any country's deliberately provocative actions. He added that the ship had been "tracked" and "warned" while on the mission to deliberately enter the disputed waters. [The United States] Defense Department spokesman ... Bill Urban had earlier said that "the United States is conducting routine operations in the South China Sea in accordance with international

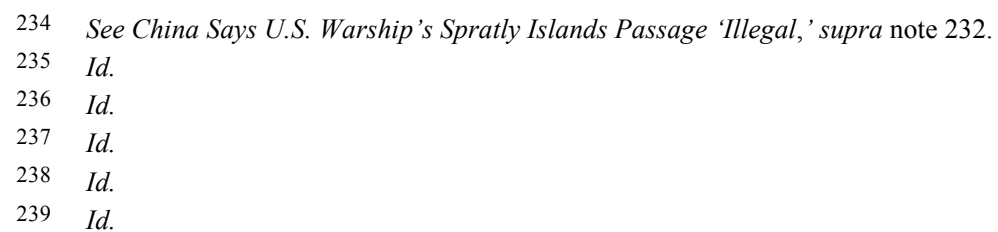


law." 240

The operation was well received by several Asian countries, including the Philippines.

The United States involvement in the South China Sea will not help alleviate tensions between the competing states. Instead, the United States' provocative actions are increasing tensions in the area and aggravating an already sensitive situation. From the statements made by Lu Kang, it is likely that China would respond by matching the United States' air and naval procedures and challenging the United States' actions in the South China Sea. Also, rather than taunting China, the United States should withdraw from the ongoing territorial dispute over the Spratly Islands. First, the United States should not be taking sides in the territorial dispute. It can continue to express its beliefs on freedom of navigation through the territorial waters in the South China Sea without specifically condemning one state's actions. Second, it is not justified in sending warships and planes over the South China Sea to strong-arm states into complying with international laws when the United States itself has not ratified many of the treaties it is trying to enforce through intimidation. Third, the United States would be more effective in encouraging the competing states to work through negotiations and establish creative solutions to the ongoing dispute. The United States can accent the advantages of treaties, negotiations, and ongoing peace for all states concerned. This would be much more effective because aggressive acts by the United States will only encourage aggressive acts by China. The other four Asian states are more than capable of holding their own weight against China and resolving this dispute peacefully. The military and aggressive actions of the United States will only cause more tension in an already tense area.

\section{F. JOINT DEVELOPMENT ZoNe AGREEMENT}

Joint Development Zones are governed by UNCLOS Articles 74(3) and $83(3){ }^{241}$ These provisions allow states to

contemplate provisional arrangements of a particular nature when they face deadlocks in negotiations over maritime delimitations.... If states cannot agree on their maritime boundaries, they can or should instead consider cooperation on the disputed maritime areas, for a transitional period,

$240 \quad I d$

241 See Tanga Biang J., The Joint Development Zone Between Nigeria and Sao Tome AND PRINCIPE: A CASE OF PROVISIONAL ARRANGEMENT IN THE Gulf of Guinea at viii (2010), http://www.un.org/depts/los/nippon/unnff_programme_home/fellows_pages/fellows_papers/tanga_0910 _cameroon.pdf. 
while remaining under the duty of carrying negotiations on. $^{242}$

Nigeria and Sao Tome and Principe were previously disputing territorial and maritime sovereignty over a group of islands off of the coast of Nigeria. ${ }^{243}$ Both states claimed to have overlapping claims to the islands. ${ }^{244}$ Rather than arbitrating the dispute through an international court or an international tribunal, the states resolved their dispute by creating a Joint Development Zone Agreement, which is regulated by a Joint Development Authority. ${ }^{245}$

Article 3(1) of that Joint Development Zone Agreement established three principles of joint development. ${ }^{246}$ The first principle is joint control of both parties over the exploration and exploitation of the resources in the joint development zone ("JDZ"). ${ }^{247}$ The second principle is optimum commercial utilization of the resources gathered in the JDZ. ${ }^{248}$ In the Nigeria and Sao Tome and Principe Joint Development Agreement, the third principle established a sixty-forty percent split of benefits and obligations in favor of Nigeria. ${ }^{249}$

Article 3(2) and 3(3) of the Joint Development Zone Agreement also established three principles that bound Nigeria and Sao Tome and Principe. ${ }^{250}$ The first is the due respect to the treaty. ${ }^{251}$ This principle established that both parties must abide by the terms of the agreement and respect the decisions Joint Development Authority with respect to the treaty and treaty interpretation. The second principle is efficient exploitation of resources. ${ }^{252}$ The parties agreed to collectively explore and exploit the resources from the islands and the surrounding seabed in a way that was time and cost effective. The third principle is diligent implementation of the treaty. ${ }^{253}$ Through this principle, the parties agreed to execute and abide by the terms established in the treaty.

242 Id

243 See Treaty Between the Federal Republic of Nigeria and the Democratic Republic of Sao Tome and Principe on the Joint Development of Petroleum and Other Resources, in Respect of Areas of the Exclusive Economic Zone of the Two States, Feb. 21, 2001, (DOALOS), http://www.un.org/depts/los/legislationandtreaties/pdffiles/treaties/stp-nga2001.pdf.

244 Id.

245 Id.

246 Id.

247 Id.

248 Id.

249 Id.

250 Id.

251 Id.

252 Id.

253 Id. 
The Joint Development Zone Agreement also includes a no prejudice clause in Article 4. ${ }^{254}$ Article 4 states that

nothing contained in this Treaty shall be interpreted as a renunciation of any right or claim relating to the whole or any part of the Zone by either State Party or as recognition of the other State Party's position with regard to any right or claim to the Zone or any part thereof. ${ }^{255}$

Also, Article 4.2 states that

no act or activities taking place as a consequence of this Treaty or its operation, and no law operating in the Zone by virtue of this treaty, may be relied on as a basis for asserting, supporting or denying the position of either State Party with regard to rights or claims over the zone or any part thereof. ${ }^{256}$

Through these two articles, both Nigeria and Sao Tome and Principe agree that, by participating in this Joint Development Zone Agreement, they are not relinquishing or solidifying any claims that they could possibly have to islands.

The ideal solution for all states involved in the Spratly Islands dispute would be to set up a Joint Development Zone Agreement much like the one created by Nigeria and Sao Tome and Principe. This would be the best plan considering that none of the states have very strong claims to the islands that they are contesting. This would prove to be especially lucrative for China, which has proved to be unwilling to work through international courts, as is evident from the facts that it is not a signatory to the ICJ and has already rejected the authority of the PCA. ${ }^{257}$

Although China has rejected the involvement of third parties in the case, China will likely be willing to work directly with the other states involved in the dispute in the South China Sea. This is evident from its signing of the Declaration on the Conduct of Parties in the South China Sea. It would also be in the best interest of all parties involved to work through a joint development zone agreement because of the weakness of their own claims and China's historic refusal to settle situations through the international courts. They would also likely be willing to work directly with China and the other states involved as is evident from their signing of the Declaration on the Conduct of Parties in the South China Sea. Furthermore, China has articulated through its position paper that it "firmly

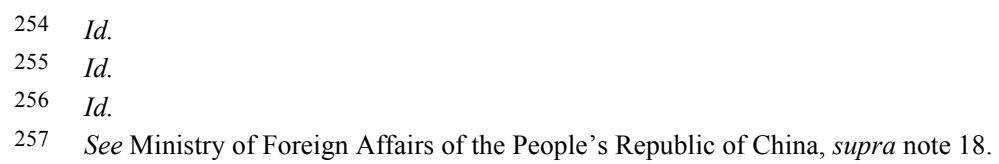


believes that the most effective means for settlement of maritime disputes between China and its neighboring States is that of friendly consultations and negotiations between the sovereign States directly concerned." 258

The ideal joint development zone agreement between China, Vietnam, the Philippines, Malaysia, and Brunei would share many of the same principles as the agreement between Nigeria and Sao Tome and Principe. In the agreement between the Asian states, there should be joint control over the exploration and exploitation of the islands and the surrounding seabed. All states involved would take part in using the waters for fishing and excavating the hydrocarbons from the seabed. Moreover, all states would agree to the optimum commercial utilization of the resources gathered in the JDZ. Although the Nigeria and Sao Tome and Principe Joint Development Zone Agreement separates the benefits and responsibilities respectively into sixty and forty per cent shares, this solution would not be acceptable to the Asian states. This would not work for the Asian states because a sixty - forty split is not functional between five states.

The states would also be responsible for establishing a Joint Development Authority to arbitrate between the states anytime an issue arises under the agreement that could not be resolved through negotiations. The Joint Development Authority would be made up of representatives from each state, and the states would agree to abide by the decisions made by the authority on matters pertaining to treaty interpretation and enforcement. While the decisions by the Joint Development Authority would be no more binding than a decision by the ICJ or the PCA, the states, particularly China, would likely be more open to abide by its decisions because the authority would be enforcing a document and agreement that each state actively participated in making. Moreover, the Joint Development Authority would only arbitrate on problems that could not be resolved through negotiations, and China has been open to negotiations and consultations with the other state parties involved in the Spratly Island dispute.

In the case of China, Vietnam, the Philippines, Malaysia, and Brunei, the best solution would be to divide the benefits and responsibilities according to present effective control. Although an international court would not look to actions that arose after the competing state asserted its claims, this does not prevent multiple states from doing differently in their treaties and agreements. For this type of agreement, each state would have to prove that it did have effective control over the island in question. It would have to establish this to the approval of the Joint Development Zone 
Authority and meet the standard established in Indonesia v. Malaysia and the Palmas Case. This should not be a difficult standard for any of the states because the majority of the islands are occupied and, in recent years, states have been working to solidify their legal claims in the South China Sea through island building and militarization. However, it would be crucial to establish that, similar to the object and purpose of Article 4 and 4.2 of the Nigeria and Sao Tome and Principe Joint Development Agreement, any decision as to effective control made by the Joint Development Agreement would not establish effective control for other purposes and would not be used to bolster any states claim in a matter outside of the Joint Development Agreement.

Each state would be responsible for excavation of the resources of the islands over which they currently have effective control. They would individually benefit from whatever they could collect from these islands and the surrounding seabed. With respect to the islands that no state has effective control over, the competing states would enter into bilateral or multilateral agreements with the states that lay claims to the islands, to resolve, between the competing states, how to divide the work and profits. These bilateral and multilateral agreements would be overseen by the Joint Development Authority and arbitrated by it should negotiations not resolve the problem.

The states that occupy islands would also have the right to the twelvenautical mile zone from the occupied island, but would have to agree to leave the southern portion of the South China Sea open for all states to freely navigate. This is crucial to help prevent third party states, like the United States, from becoming involved in the Spratly Island dispute. The United States has been vocal through the press and its Freedom of Navigation Exercises that its presence throughout the Spratly Islands is to ensure that China does not prevent states from navigating through these waters. This sea is of particular importance to third party states because it is rich in fishing lanes and necessary for trade with many East Asian states. If any state were to close off this area from the presence of foreign ships, these foreign ships and their respective states and businesses, would not have an outlet or means of reaching many of the East Asian ports for trade. Because of the high value of trade, and the desire to keep third parties uninvolved in this dispute, it is necessary for the five competing states to leave this area open to foreign ships and stress their commitment to freedom of navigation throughout the Spratly Islands. For this to work, the states would also have to demilitarize whatever islands they are occupying. Having the islands militarized only serves to escalate tensions between the competing states and third party states, and would cause unnecessary stress to whatever peaceful negotiations and plans the states would have. 
The Asian states would likely be open to this type of agreement, as is evident from their past attempts to work through bilateral and multilateral agreements. In the past, China has entered into numerous bilateral treaties with the states involved in the dispute. It has also entered into multilateral conventions with other Asian states. Also, the states have previously expressed their desires to work with each other and go through third parties to resolve the ongoing dispute in the Spratly Islands. Vietnam, the Philippines, Malaysia, and Brunei will likely also be open to working through bilateral treaties because they will be able to negotiate agreements that best serve their interests, and the other disputing states will likely honor these agreements.

\section{CONCLUSION}

While the Spratly Islands are generally too small and arid to support permanent settlements, have limited fresh water sources, and few significant mainland resources, their value to China, Vietnam, the Philippines, Malaysia, and Brunei lies in their strategic, political, and economic worth. Throughout history these five states have been laying claims to this group of islands with varying levels of success. The claims range from discovery, occupation, and uti possidetis, to claims based on proximity and UNCLOS.

Although the claims made by the states are many, their legal justifications are few. In light of the decision of the ICJ in Indonesia $v$. Malaysia, and of the decision by the PCA in the Palmas Case, none of the states have taken the requisite actions necessary to establish sovereignty over the Spratly Islands. The actions of the states do not evince the necessary intention to act as sovereign; display and exercise of authority over the disputed area; or maintained control, which is needed to prove effective control. Moreover, the claims that arise from UNCLOS stem from a misreading of the convention and are therefore insufficient to establish sovereignty.

In recent years, tensions in the South China Sea have escalated drastically. China's unprecedented island building has been a cause for concern for the competing states, and the United States' Freedom of Navigation exercises have been a cause of concern for the Chinese government. Also, the increased militarization of the area by the states involved in the dispute is a major concern. Because of the escalating tensions, it is of the utmost importance that the Spratly Islands dispute be resolved as quickly as possible.

Because of the flawed claims by the states, and China's historic refusal to work through international courts, the best and quickest resolution would 
be to establish a Joint Development Zone Agreement between the five competing states. This would work to help ease the tensions between China, Vietnam, the Philippines, Malaysia, and Brunei because it would encourage peaceful negotiations and shared responsibilities to explore and exploit the resources in the South China Sea.

The ongoing territorial and maritime dispute over the Spratly Islands is an example of the shortcomings of the international court system. Even though all these states have competing claims to the islands, under the existing law, none of their claims would be sufficient to establish sovereignty. This has led to the militarization of the area and rising tensions that the courts are currently incapable of solving. Even though the courts will not resolve this dispute, the Joint Development Zone Agreement between Nigeria and Sao Tome and Principe exemplifies the power of peaceful negotiations. In that case, the answer to the problems that arose from overlapping claims came from bilateral, peaceful negotiations and the direct involvement of the competing parties without the intervention of third party states or organizations. Similarly, the answer to the problem in the Spratly Islands will only arise from the five competing states working together without third party intervention. China, a global economic and military force, has seen the benefits of these types of negotiations. It has encouraged peaceful discussions and condemned third party involvement in an effort to resolve the historical dispute; an approach that would be beneficial for any states currently involved in maritime or territorial disputes. Although China, Vietnam, the Philippines, Malaysia, and Brunei have been unable to resolve the on-going problems in the South China Sea, peaceful and continuous negotiations would be the ideal solution to cut the Gordian knot that has arisen over the Spratly Islands. 